\begin{tabular}{|l|l|l||}
\hline \multicolumn{2}{|c|}{ PublisherInfo } \\
\hline \hline PublisherName & $:$ & BioMed Central \\
\hline \hline PublisherLocation & $:$ & London \\
\hline \hline PublisherImprintName & $:$ & BioMed Central \\
\hline \hline
\end{tabular}

\title{
A transfusion-independent method for treating ICU-associated anemia
}

\begin{tabular}{|l|l|l||}
\hline \multicolumn{2}{|c|}{ ArticleInfo } \\
\hline \hline ArticleID & $:$ & 4184 \\
\hline \hline ArticleDOI & $:$ & $10.1186 /$ ccf-2000-4030 \\
\hline \hline ArticleCitationID & $:$ & 4030 \\
\hline \hline ArticleSequenceNumber & $:$ & 43 \\
\hline \hline ArticleCategory & $:$ & Paper Report \\
\hline ArticleFirstPage & $:$ & 1 \\
\hline \hline ArticleLastPage & $:$ & 3 \\
\hline \hline & & RegistrationDate : 2000-1-14 \\
\hline ArticleHistory & $:$ & OnlineDate \\
\hline \hline ArticleCopyright & $:$ & Current Science Ltd2000-1-14 \\
\hline \hline ArticleGrants & $:$ & \\
\hline \hline ArticleContext & $:$ & 1305422 \\
\hline \hline
\end{tabular}




\section{Keywords}

Anemia, blood substitutes, blood transfusion, erythropoietin, intensive care unit, transfusion medicine

\section{Comments}

This study is admirable for its design and questioning of a common clinicalscenario. It suggests a practical, clinically available alternative to bloodtransfusion in this 'at risk' population which would avoid the hazards ofblood transfusion. The authors, using the results from the study, were ableto suggest reasons for the anemia seen in ICU patients which need furtherinvestigation to fully elucidate the pathophysiology involved.Note however, that in the method, the authors did vary from routine clinicalpractice within the UK, by giving all enrolled patients oral ironfrom the start of the study, or as soon as bowel sounds were present.

\section{Introduction}

Much recent interest has been focused on the transfusionrequirements of intensive care unit (ICU) patients and how best to reduce patient exposure tounnecessary transfusions (and so avoid the associated risks). Previous workhas identified the ICU population as having a transfusion requirement of 2-4units/ week.ICU patients, particularly those with sepsis, appear unable to mount anerythropoietic response to compensate for their anemia. It is uncertainwhether this is as a result of inappropriately low erythropoietin productionfor the hemoglobin level or a failure to respond to endogenouserythropoietin.

\section{Aims}

This study aimed to determine whether the administration ofrecombinant human erythropoietin (rHuEPO) to critically ill patients wouldreduce the requirements for red blood cell (RBC) transfusions.

\section{Methods}


The study was a prospective, randomized, double-blind,placebo-controlled trial carried out in three tertiary care ICUs andstudied a total of 160 patients (80 in each of the placebo and rHuEPOgroups). Patients who fulfilled the study criteria were randomized andentered the trial on day 3 of their ICU admission. $\mathrm{rHuEPO}$ was administeredsubcutaneously at a dose of 300 units $/ \mathrm{kg}$ for a total of 5 days. Subsequently, the study drug was administered on alternate days for aminimum of 2 weeks, or until ICU discharge. The rHuEPO was temporarilywithheld when the hematocrit (Hct) reached $>38 \%$ and restarted when the Hctfell below 38\%.Outcomes examined were cumulative blood transfusion requirements during the study period and transfusion independence between study days 8 and 42 .

\section{Results}

Of 1778 patients admitted to the three ICUs over the studyperiod, 329 were eligible but only 160 were enrolled (most commonly due torefusal to consent). The study populations were well matched and did notdiffer from the patients who did not consent to participate in the study.Cumulative transfusion requirements for the $\mathrm{rHuEPO}$ group were significantlyless than the placebo group (166 total units in the rHuEPO group versus 305 totalunits for the placebo group). Each patient received a mean of $8.3 \pm 4.5$ dosesof rHuEPO. When transfusion independence was examined, $45 \%$ of patients in the rHuEPO groupeither received a blood transfusion between day 8 and 42 or died beforestudy day 42, compared to $55 \%$ patients in the placebo group. There was nosignificant difference in the two groups in mortality or adverse events.

\section{Discussion}

The authors conclude that administration of rHuEPO to ICUpatients resulted in a significant reduction in blood transfusion requirements. They also concluded that the ability of this ICU population torespond to $\mathrm{rHuEPO}$ may indicate that the anemia seen in this population isdue to a blunted erythropoietic response, as well as an impaired ability torespond to endogenous erythropoietin. They suggested that further studieswere needed to identify the potential benefits of avoiding RBCtransfusion.

\section{References}

1. Gettinger A, Rodriguez RM, Pearl RG, Gubler KD, Enny C, Colton T, Corwin MJ: Efficacy of recombinant human erythropoietin in the critically ill patient: a randomized, double-blind, placebocontrolled trial. Crit Care Med. 2000, 27: 2346-2350.

This PDF file was created after publication. 